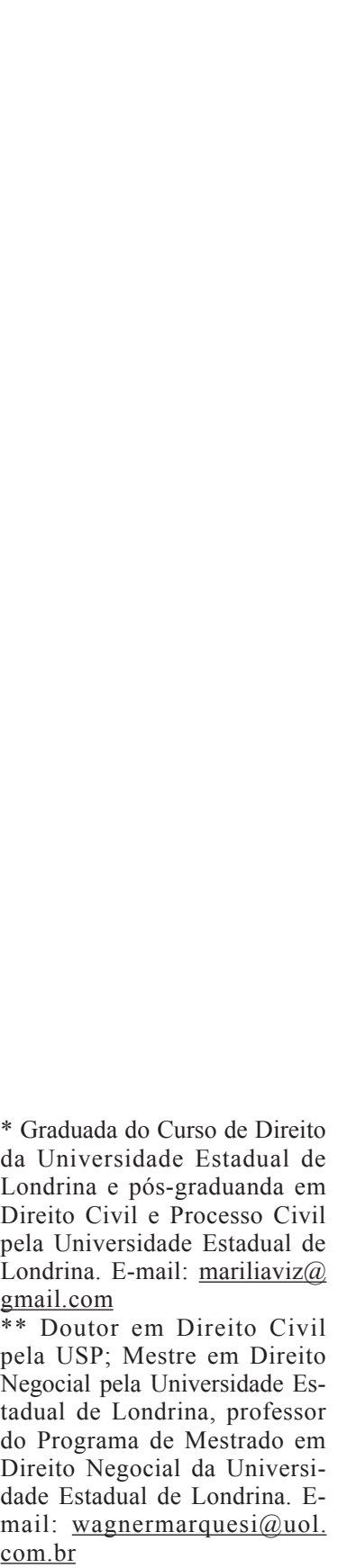

\title{
Responsabilidade Civil do Médico Imperito
}

\section{Civil Liability and medical Malpractice}

\author{
Marília Vizzoto * \\ Roberto Wagner Marquesi $* *$
}

Resumo: O artigo busca explicar os elementos que compõem a responsabilidade civil e aplicá-los à atividade médica danosa, explanando seu conteúdo negocial. Trata da responsabilidade do médico, enquanto profissional liberal, por erro derivado de imperícia, perquirindo sobre suas causas e consequências e trazendo propostas de prevenção. Apresenta o percurso histórico do tema e discute sua importância social.

Palavras-chave: Direito de danos. Médico. Responsabilidade civil.

Abstract: The article seeks to explain the elements that compose the civil liability and aply them to medical liability, explaining it's negotial nature. Considers the civil liability of the doctor, as a liberal professional, for malpractice, questioning it's causes, consequences and bringing proposals of prevencion. Presents the evolution of the theme and it's social relevance.

Keywords: Damage law. Doctor. Civil liability. 


\section{INTRODUÇÃO}

Dada a importância da medicina para a sociedade, o exercício dessa atividade profissional sempre foi regulado pelo direito.

Conquanto exaustivamente discutido, o tema da responsabilidade civil do médico permanece atual e suscita grandes controvérsias.

Com a crescente proliferação de escolas médicas no Brasil, a falta de estrutura das que existem e a transformação do conhecimento em produto comercializável, surge o problema da imperícia médica. Existem hoje profissionais que deixam as escolas de medicina mal preparados e com conhecimento insuficiente para a prática, situação que leva ao cometimento de erros eivados de imperícia. Mesmo entre os atuantes há longa data, existe o problema da conduta imperita, pois não há entre alguns profissionais a cultura da atualização, do estudo contínuo e do aperfeiçoamento.

A realidade brasileira mostra que, na maioria das vezes, as fatalidades na atividade médica ocorrem por motivos alheios à conduta culposa médica, como, por exemplo, a impossibilidade de cura, o desproporcional índice entre médicos e pacientes, a falta de estrutura e de recursos dos hospitais, a situação sanitária precária e a falta de conhecimento dos próprios pacientes. Porém, vezes há em que a causa da fatalidade é o comportamento imperito do profissional da medicina, o que deixa a sociedade em posição vulnerável e a vítima a exigir reparação.

A responsabilização civil no âmbito médico é fenômeno de crescente importância, dada a conscientização dos pacientes acerca de seus direitos e ao crescimento de demandas dessa natureza. O presente artigo aborda este fenômeno e, para este fim, considerara apenas o médico profissional liberal.

Apresentam-se, aqui, considerações sobre a responsabilidade médica, estabelecem-se parâmetros para a caracterização da imperícia, enfatizamse as medidas preventivas e as formas de combater essa conduta, trazendo parâmetros para garantir efetiva indenização à vítima, sem tornar o exercício da medicina impraticável economicamente.

\section{ELEMENTOS DA RESPONSABILIDADE CIVIL}

Quando alguém age de maneira descuidada, em desconformidade com a lei e causa prejuízo a outra pessoa, ele desfaz o equilíbrio que sustenta a vida 
em sociedade. O mecanismo para restabelecer esse equilíbrio é a responsabilidade civil.

Ela se foca no prejuízo causado pelo ato danoso advindo do descumprimento culposo de um dever.

Segundo o artigo 927 do Código Civil, aquele que por ato ilícito causar dano a outrem fica obrigado a repará-lo. O conceito de ilícito a que este artigo se refere (ilícito em sentido estrito) está na conjugação dos artigos 186 e 187, ambos do Código Civil, ou seja, conduta culposa que, ao violar dever jurídico, viola direito de outrem e lhe causa dano. O dever jurídico agredido poderá ser contratual ou extracontratual, conforme a natureza da obrigação que lhe deu origem.

Haverá responsabilidade contratual quando o dever violado advier de obrigação voluntária, criada por negócio jurídico. A responsabilidade extracontratual ou aquiliana advém de violação de obrigação estabelecida por lei ou extraída da interpretação sistemática da ordem jurídica.

Desse modo, o ilícito stricto sensu tem como elementos a conduta antijurídica, a culpa, o dano e o nexo de causalidade entre eles.

\subsection{Conduta}

Relativamente à conduta, haverá uma ação contrária ao direito, ou uma omissão que também o será, pois realizada por quem tinha o dever de agir. Esta conduta será voluntária e também será controlável pelo agente.

Além de violar direito de outrem a conduta será qualificada pela culpa.

O Código Civil, ao tratar da responsabilidade subjetiva, não menciona a conduta dolosa, mas tanto a conduta culposa quanto a dolosa, quando contrárias ao direito e danosas, geram dever de indenizar. A conduta culposa em sentido estrito vem a ser aquela qualificada pela imperícia, imprudência ou negligência. Já a culpa em sentido amplo engloba tanto a culpa em sentido estrito quanto o dolo; a conduta dolosa é aquela qualificada pela intenção deliberada de violar o dever jurídico, de produzir resultado ilícito.

No âmbito da responsabilização civil, a culpa, em todos os seus graus e modalidades e o dolo, são equiparados. A culpa levíssima é suficiente para caracterizar a responsabilidade civil. O grau de culpa, porém, poderá influenciar na fixação da indenização, segundo preconizam os artigos 944 e 945 do Código Civil. 
Pertinente definição de culpa em sentido estrito traz Sergio Cavalieri Filho (2008, p.34): "pode-se conceituar a culpa como conduta voluntária contrária ao dever de cuidado imposto pelo Direito, com a produção de um evento danoso involuntário, porém previsto ou previsível". Ressalta o autor que, na ausência de normas concretas indicando o comportamento correto, o conteúdo do dever de cuidado será indicado pela comparação da conduta concreta do agente com o comportamento que teria adotado, em seu lugar, um homem diligente, que os romanos chamariam bonus pater familiae.

O resultado ilícito, se não previsto, deve ao menos ser previsível, pois "só há o dever de evitar o dano que for razoável prever" (CAVALIERI FILHO, 2008, p.35), sob o risco de responsabilizar o agente por caso fortuito ou força maior.

Ainda segundo o mesmo autor, a previsibilidade será determinada tanto pelo critério objetivo quanto pelo critério subjetivo. A previsão do resultado deve ser exigida de um homem comum e cuidadoso, porém não se deve desconsiderar as condições pessoais e peculiares do sujeito.

A culpa se exterioriza na conduta através da negligência, imprudência e imperícia. A primeira é a conduta omissiva que revela falta de cuidado. A imprudência é a falta de cuidado revelada em conduta comissiva, é um agir precipitada e perigosamente. Por fim a imperícia é a falta de habilidade no exercício de atividade técnica.

\subsection{Dano}

Contudo, sem dano não há que se falar em responsabilidade civil, pois não há nada para ser reparado.

O dano é a subtração ou diminuição de um bem jurídico, tanto patrimonial quanto moral (CAVALIERI FILHO, 2008, p.71). Poderá ser atual ou futuro, porém deverá ser real e efetivo, não se considerando um dano que pode vir a ocorrer, dano hipotético ou eventual. Deve restar comprovada a repercussão do fato lesivo sobre a vítima.

O dano será patrimonial quando atingir o conjunto de relações jurídicas apreciáveis em dinheiro. Este tipo de dano é determinado pela comparação do patrimônio existente com aquele que existiria se o dano não houvesse ocorrido. 
O dano patrimonial engloba lucro cessante e dano emergente, sendo o último o que o sujeito passivo efetivamente perdeu e o primeiro, o ganho que o lesionado provavelmente teria, mas deixou de auferir em decorrência do dano infligido, a avaliação deste ocorrendo pelo desenvolvimento normal dos acontecimentos, tendo em vista uma possibilidade objetiva de lucro.

O dano moral estará presente, via de regra, quando a lesão for a interesses não patrimoniais, como aos direitos da personalidade, porém a lesão poderá ser a bem jurídico patrimonial e seus efeitos repercutirem na esfera moral do indivíduo. Logo, o dano moral será a lesão a bem jurídico, patrimonial ou moral, que repercutirá na esfera moral do indivíduo (DINIZ, 2008, p.88).

O direito repara apenas a dor e sofrimento decorrentes da lesão a um bem jurídico reconhecido e protegido por lei, logo a dor e a aflição espiritual são apenas consequências do dano moral.

Concordam tanto a doutrina quanto a jurisprudência que o dano patrimonial e moral são cumuláveis e o Código Civil consagrou, em seu artigo 186, a reparação do dano exclusivamente moral (BARROS JÚNIOR, 2007, p.57).

$\mathrm{Na}$ responsabilização civil, que busca, tanto quanto possível, tornar a vítima indene, é sempre preferível a reparação de modo específico, buscandose atingir situação material que corresponderia à situação real se não houvesse ocorrido o dano.

Como no âmbito moral não há direta equivalência entre o bem lesionado, o dano e a indenização, a reparação é comumente feita de forma pecuniária. Ante a impossibilidade de retornar ao status quo ante, visa atenuar o sofrimento e não tem a pretensão de tornar a vítima indene.

O dano estético é modalidade de dano moral e consiste, segundo Teresa Ancona Lopez (2004, p.46), em qualquer modificação duradoura na aparência externa que cause à pessoa lesada um "enfeamento", humilhação e desgosto, originando-lhe uma dor moral.

O dano moral, ainda segundo a citada autora, divide-se em objetivo (aquele que ofende os direitos da personalidade, por exemplo, a integridade física), subjetivo (sofrimento do indivíduo atingido em seus valores íntimos) e finalmente o dano moral e a imagem social (rejeição social e repulsa).

Além de eventual indenização por danos materiais, será cumulável, em caso de dano estético, a indenização por dano moral objetivo (ofensa a integridade física) e a indenização por dano moral à imagem social, se o dano causar repulsa à própria vítima e a terceiros (LOPEZ, 2004, p.164). 


\subsection{Nexo de causalidade}

Entre a conduta antijurídica culposa e o dano deve existir um nexo de causalidade. A conduta deve ser a causa do dano.

É causa o antecedente sem o qual o resultado não teria ocorrido, desde que esse antecedente, quando considerado abstrata e isoladamente, se revele idôneo para produzir o resultado. A causa deve ser o antecedente que teve interferência decisiva na produção do resultado (CAVALIERI FILHO, 2008, p.49).

A culpa exclusiva da vítima, a culpa de terceiro e o caso fortuito ou força maior, que são eventos inevitáveis ou imprevisíveis e estranhos à vontade do agente, elidem o nexo causal entre o evento danoso e a conduta do agente, impossibilitando a responsabilização (DINIZ, 2008, p.110).

O nexo causa é que possibilita apurar a autoria do ilícito.

\section{RESPONSABILIDADE CIVIL DO MÉDICO}

A finalidade da medicina é prevenir e atenuar os males da humanidade (KFOURI NETO, 2010, p.27). A medicina deve ser exercida cautelosamente, com competência, amor e respeito à vida e aos direitos do paciente (CROCE; CROCE JÚNIOR, 2002, p.4). Desse modo, os médicos sempre devem atuar no ânimo de curar, pautados pelo princípio da beneficência.

Erros, porém, acontecem.

Aponta-se como motivo do crescimento das demandas sobre erro médico principalmente a deterioração do serviço, sem embargo de outros fatores, como a despersonalização da relação médico paciente, a polemização do erro médico pela imprensa, cansaço e estresse da atividade. Estima-se que o Brasil forma 14 mil médicos por ano, que se juntam aos aproximadamente 390 mil atuantes (Conselho Federal de Medicina, 2011). O número absoluto de médicos é grande, porém mal distribuído.

$\mathrm{Na}$ antiguidade, a responsabilidade do médico era objetiva, se o paciente não fosse curado o médico era severamente punido, considerava-se que ele havia falhado ao representar um instrumento divino. Com a evolução das sociedades houve um distanciamento entre o médico e a figura de uma divindade. Consequentemente, a responsabilidade médica passou a ter critérios mais racionais e basear-se na conduta culposa. 
Não se deve olvidar que a ciência médica não é, e nem pretende ser, uma ciência exata; ao lidar com a complexidade do organismo humano, resultados diferentes são obtidos na aplicação de um mesmo tratamento em pessoas diversas, dado a inúmeros fatores particulares e genéticos.

Também é de ter em mente que não é o médico que põe a saúde do paciente em risco, mas a doença. E na maioria das vezes a impossibilidade de cura decorre da natureza humana, que é mortal ou da falta de conhecimento da ciência médica, que, apesar do seu desenvolvimento, ainda não alcançou o grau da perfeição. Como responsabilizar o médico por isso?

O Código de Defesa do Consumidor, em seu artigo 14, $\S 4^{\circ}$, estabeleceu para os médicos profissionais liberais a responsabilidade subjetiva. Profissional liberal é aquele que, ao prestar serviço, atua em nome próprio e não tem vínculo de subordinação com quem o remunera (MELO, 2008, p.13).

Segundo Miguel Kfouri Neto (2010, p.74), a obrigação do médico é contratual, apesar de excepcionalmente originar-se fora do âmbito contratual, como no caso de médico que socorre vítima inconsciente na rua. Apesar de alguma divergência, a maioria da doutrina e jurisprudência pátria classifica essa relação contratual como locação de serviços em sentido amplo.

A obrigação médica também é de meio ou diligência, ou seja, ele assume o dever de praticar sua atividade de acordo com as regras de métodos recomendados pela sua profissão, proporcionando ao paciente os cuidados necessários e condizentes com o avanço científico (KFOURI NETO, 2010, p.75).

É o que se depreende do seguinte acórdão, prolatado pela segunda turma do Superior Tribunal de Justiça:

[...] O Superior Tribunal de Justiça vem decidindo que a relação entre médico e paciente é de meio, e não de fim (exceto nas cirurgias plásticas embelezadoras), o que torna imprescindível para a responsabilização do profissional a demonstração de ele ter agido com culpa e existir o nexo de causalidade entre a sua conduta e o dano causado - responsabilidade subjetiva, portanto [...] (REsp 1184932/PR, Rel. Ministro CASTRO MEIRA, SEGUNDA TURMA, julgado em 13/12/2011, DJe 16/02/2012).

O médico, no exercício de seu mister, raramente terá a intenção de prejudicar seu paciente. Qualquer erro cometido muito provavelmente será culposo, derivado da não observação de dever de cuidado. 
Caberá à vítima o ônus de provar que o médico falhou e que este comportamento foi eivado de culpa e lhe causou dano.

É necessário que tenha sido possível ao médico agir com mais vigilância e que a ignorância sobre determinado ponto não seja admissível para sua profissão (CROCE; CROCE JÚNIOR, 2002, p.11).

A perícia médico legal é o caminho mais indicado para fazer prova do erro, da culpa e do nexo causal. Todavia, a perícia não vincula o magistrado, podendo ele inclusive decidir de modo contrário a ela se o conjunto probatório lhe der razão para isso (KFOURI NETO, 2010, p.85). Neste sentido:

[...] Determina o art. 131 do CPC que o “juiz apreciará livremente a prova, atendendo aos fatos e circunstâncias constantes dos autos, ainda que não alegados pelas partes; mas deverá indicar, na sentença, os motivos que Ihe formaram o convencimento." (grifo) 2. Na hipótese em que a ação proposta tem fundamento na existência de erro médico, uma vez que realizada perícia, deve o julgador indicar os motivos pelos quais resolve concluir pela obrigação de indenizar, tomando posição oposta às conclusões do perito [...] (STJ.AgRg no AREsp 14.705/RS, Rel. Ministro HUMBERTO MARTINS, SEGUNDA TURMA, julgado em 13/09/2011, DJe 21/09/2011).

Contudo, em sede doutrinária, Barros Júnior (2007, p.144-147) defende que a prova pericial seria vinculante quanto à existência do dano, visto que se trata de matéria científica, a qual, segundo o autor, só se decide mediante prova técnica.

O referido autor também preconiza que, quando antagônicos os laudos da perícia e dos assistentes técnicos, o juiz, para esclarecer eventuais dúvidas, poderá se valer de juntas médicas ou da figura do perito desempatador.

$\mathrm{Na}$ apuração da culpa, o julgador deve lastrear-se em um médico prudente, diligente e possuidor do conhecimento que em tese deve ter, o qual, em idênticas condições, teria agido da mesma forma que o autor do prejuízo.

Como os processos por erro médico no âmbito cível têm tramitação muito longa, para imprimir maior celeridade, recomenda-se (KFOURI NETO, 2010, p.86 e ss.) que o magistrado, ao requisitar a perícia, saiba qual a principal questão a ser elucidada e elabore quesitos que lhe sejam úteis. A má formulação de quesitos, pelas partes ou pelo juiz, pode levar a um laudo pericial obscuro e vago. 
Também serviria melhor ao interesse da justiça que somente um médico especialista avaliasse a conduta de outro, de sua mesma especialidade, pois um generalista ou médico de outra especialidade, em regra, não teria o rigor nem os conhecimentos necessários para essa avaliação. Este é o posicionamento de Edimilson de Almeida Barros Júnior (2007, p.146) e Irany Novah Moraes (1998, p.352).

A prova testemunhal de leigos em questões médicas não é de grande utilidade, devido à ignorância técnica e a impressionabilidade da maior parte das pessoas nesses assuntos (CASTRO, 2005, p.184). As partes, para ajudar na produção da prova pericial, devem, sempre que possível, indicar assistentes técnicos para acompanhar o perito.

Em matéria de direito médico, prova cabal e irrefutável é muito difícil, por isso os juízes devem evitar um rigor excessivo na exigência da prova da culpa e do nexo causal, sob pena de injustamente negar o direito da vítima.

Importante ressaltar que não é qualquer lesão causada por ato médico que será indenizável. A lesão deve derivar de conduta antijurídica. Uma cirurgia necessária, por exemplo, só pode ser feita por incisão, que não deixa de ser uma ofensa à integridade física. $\mathrm{O}$ ato médico obedece às seguintes prioridades: preservação da vida, função, órgão e preservação estética (CASTRO, 2005, p.28).

Como foi explicado, o dano deve estar ligado à conduta culposa do médico para haver responsabilidade deste. Juridicamente existe causa quando uma coisa é seguida de outra, de modo que a primeira é a razão da existência da segunda (KFOURI NETO, 2010, p.122). Erroneamente, alguns pacientes e seus responsáveis confundem a não realização de suas expectativas com erro médico.

Vejam-se as modalidades de erro.

O erro grosseiro é a conduta profissional que fere os mais elementares conhecimentos da matéria médica (MELO, 2008, p.83), em casos como este a perícia inclusive poderia ser dispensada quando da verificação da culpa do médico, pois uma vez considerada uma conduta tão descabida presume-se que houve pelo menos negligência, imprudência ou imperícia.

Já o erro escusável não é aquele originado da falta de observância das regras e princípios da medicina, mas sim aquele derivado da imperfeição da ciência e da precariedade dos conhecimentos humanos (CROCE; CROCE JÚNIOR, 2002, p.32). O erro invencível pelo conhecimento médio esperado 
de um médico também é escusável, já que não é razoável esperar que ele seja um expert em todas as especialidades da medicina.

A maioria dos erros de diagnóstico também é escusável, pois, dada a natureza conjectural da diagnose e a complexidade do organismo humano, uma certeza diagnóstica, por vezes, é rara. Existem inúmeras doenças ainda não catalogadas e das catalogadas ainda não se conhecem as causas e respectivas curas de todas (MORAES, 1998, p.227). Além disso, contribuem para uma incerteza diagnóstica o histórico clínico precário e informações muitas vezes falsas ou distorcidas.

Se, apesar de errar o diagnóstico, o médico acertar a conduta, o erro não será considerado para fins de responsabilidade civil, pois dele não adveio dano (CASTRO, 2005, p.140).

Contudo, apesar da maioria dos erros de diagnóstico se encaixar na definição de erro escusável, haverá responsabilidade quando o médico revelar conduta culposa no modo pelo qual realizou o diagnóstico errôneo.

É a inteligência do acórdão proferido pela oitava câmara cível do Tribunal de Justiça do Paraná:

“[...] O diagnóstico equivocado não gera, por si só, obrigação indenizatória, mas apenas quando o médico não revela o cuidado exigível na conduta diagnosticada" (TJPR - 8 C.Cível - AC 825484-8 - Londrina - Rel.: José Laurindo de Souza Netto - Unânime - J. 08.03.2012).

Além da conduta culposa na realização do diagnóstico, o erro deve causar dano ao paciente para que haja possível responsabilização.

\section{A INVERSÃo DO ÔNUS DA PROVA NO ÂMBITO DA RESPONSABILIZAÇÃO DO MÉDICO}

A prova no processo serve para o convencimento do juiz, o ônus da prova é a indicação feita pela lei de quem deve produzir determinada prova (BUENO, 2009, p.246). Basicamente, cada parte tem o ônus de provar o que alega, porém a inversão desse ônus é permitida, por exemplo, como no Código de Defesa do Consumidor, que a admite em favor do consumidor.

Julga-se, contudo, equivocada a inversão do ônus da prova em demandas indenizatórias por erro médico. Miguel Kfouri Neto (2002, p.58) acredita que o próprio Código de Defesa do Consumidor veda a inversão no caso da discussão 
da responsabilidade de profissionais liberais e a condiciona à verificação da culpa. Culpa esta que é exigida nos dispositivos que tratam da responsabilidade médica, artigos 186, 167 e 927 do Código Civil, conjugados com o artigo 14, §4 do Código de Defesa do Consumidor. A culpa deve efetivamente ser provada, não bastando que o médico deixe de comprovar que não houve culpa para ser responsabilizado.

Na visão do referido autor, apesar da vedação da inversão do ônus da prova as partes devem participar o máximo possível da atividade probatória, desapegando-se da rigorosa repartição do ônus feita pelo Código de Processo Civil. Na audiência de instrução e julgamento, o juiz deve, a par dos argumentos das partes, precisar o objeto de prova e delegar às partes a função de auxiliá-lo a elucidar os fatos, em aceitação da teoria da carga probatória dinâmica.

Esta teoria propõe que a distribuição do ônus da prova obedeça também às peculiaridades do caso concreto e dos litigantes e não somente à norma do artigo 333 do Código de Processo Civil (BUENO, 2009, p.248). Edmilson de Almeida Barros Júnior (2007, p.139) defende que, em matéria de direito médico, esta teoria deve ser sempre aplicável.

Porém, autores há que não vêem incompatibilidade entre a responsabilidade subjetiva dos médicos e a inversão do ônus do ônus da prova (LOPEZ, 2004, p.111), (MELO, 2008, p.176).

\section{RESPONSABILIDADE CIVIL DO MÉDICO IMPERITO}

Dentro da deterioração dos serviços médicos, grave problema apontado é a falta de preparação de alguns médicos. Dados de 2010 (CREMESC, 2010) mostram que o Brasil possui 181 escolas de medicina, a transformação do ensino em produto comercializável contribuiu para a proliferação das faculdades e para queda na qualidade do ensino. Chegando ao ponto de novas escolas de medicina terem suas instalações permitidas sem o pré-requisito mínimo do hospital-escola (MORAES, 1998, p.46).

O exame voluntário feito pelo Conselho Regional de Medicina do Estado de São Paulo (CREMESP) em 2008 avaliou o desempenho dos estudantes do sexto ano do curso de Medicina das escolas do Estado de São Paulo, e obteve um índice de reprovação de 61\%. O índice em 2005 era de 31\%. Entre os recém-formados, $75 \%$ acreditam que os cursos de Medicina deveriam ser mais exigentes (CREMESP, 2009). 
De um lado, as escolas de medicina estão deficientes, de outro, a ciência médica progrediu muito, a quantidade mínima do saber a ser aprendido aumentou de modo exponencial, a ponto de nenhum recém-graduado sentir-se plenamente capaz de exercer a profissão apenas com o diploma universitário (MORAES, 1998, p.46).

A residência é essencial à boa formação do médico, já que é a única forma de ganhar experiência sem os riscos de atuar sozinho (KFOURI NETO, 2002, p.21). Porém a residência não é acessível a todos os médicos que se diplomam no País, estima-se que o Brasil treine razoavelmente apenas um terço dos graduados em medicina (MORAES, 1998, p.55).

Nos dizeres de Moraes (1998, p.287), "na medicina antiga, a mínima extensão dos conhecimentos permitia que o médico tivesse a impressão de dominá-los". Hodiernamente, em vista da quantidade extremamente grande dos conhecimentos e dos recursos médicos, impõe-se o fracionamento desse conhecimento em especialidades, já que não é razoável esperar que um homem comum seja capaz de dominar todas as áreas de uma ciência.

\subsection{Imperícia médica}

A imperícia é definida como conduta que revela falta de conhecimento acerca da profissão. Decorre muitas vezes do despreparo prático ou da falta de conhecimento acerca das normas que disciplinam a conduta a ser realizada.

Genival França, citado por Miguel Kfouri Neto (2010, p.105), entende que o médico habilitado, mesmo agindo de modo que revele imperícia, imperito não poderá ser considerado, pois possui diploma que lhe confere habilitação legal e está regularmente registrado em órgão competente, haveria, desse modo, uma presunção de perícia a seu favor.

Esse posicionamento, porém, não é acolhido pela maioria da doutrina e jurisprudência brasileiras, que não conferem ao diploma universitário uma presunção de perícia. O próprio Código de Ética Médica, Resolução n ${ }^{\circ} 1.931$, de 17 de setembro de 2009, reconhece a existência de imperícia da conduta médica em seu artigo primeiro.

Não se cogita na imperícia de um não habilitado, um não-médico que exerce a medicina de forma imperita e causa dano a outrem não é responsabilizado por culpa na modalidade da imperícia, estando, eventualmente, caracterizado outro tipo de ilícito. Logo, no caso do falso médico, não há que se 
falar em imperícia, pois ele não está apto para o exercício da medicina, age com imprudência.

É irrelevante a falta de consciência do médico quanto aos seus conhecimentos e capacidade, a imperícia é determinada objetivamente, confrontando uma conduta hipotética caracterizada pela perícia médica, com a conduta do agente, nas mesmas circunstâncias (KFOURI NETO, 2010, p.104-105).

O médico, diante de um caso que lhe gere dúvidas ou supere seu conhecimento, deve procurar suprimir essas dúvidas antes de agir ou indicar ao paciente um especialista ou um médico mais experiente.

Não é a falta de conhecimento genérica que torna um médico imperito, mas a ação pautada na ignorância, ignorância esta que deve ser daquilo que um médico, com o grau de especialização dele, deveria saber.

Um médico ortopedista, por exemplo, que engessa uma pessoa acidentada, que chega com fratura exposta, é imperito, porque o procedimento é adequado para fratura fechada.

Revela imperícia médico que prescreve medicamento acima da quantidade adequada, que confunde veia safena com artéria femoral durante safenectomia, que provoca queimaduras em paciente durante radioterapia (CROCE; CROCE JÚNIOR, 2002, p.25), médico que confunde artéria e veia durante cirurgia de varizes e extrai a artéria femoral, determinando a amputação da perna devido a gangrena (MORAES, 1998, p.359).

O Conselho Regional de Medicina do Estado de São Paulo (CREMESP) divulgou em 2008 que no Estado de São Paulo 47\% dos 92.580 médicos atuantes não têm título de especialista, apesar de na prática muitos exercerem especialidades médicas (CREMESP, 2008).

É presumida a imperícia na conduta do médico que erra ao realizar intervenções próprias de especialista sem o ser. Neste caso, além de imperícia, a conduta se revela altamente imprudente (KFOURI NETO, 2010, p.105).

A imperícia também será avaliada em relação aos progressos científicos e tecnológicos disponíveis à época e ao profissional. O médico desatualizado também poderá ser reputado imperito quando o desuso de determinada prática for notório.

Entretanto, deve ser considerado que no Brasil há cidades de difícil acesso e com escassos recursos no âmbito da tecnologia médica, por isso devem ser analisados os recursos disponíveis no caso concreto ao médico considerado. 


\subsection{Erro de diagnóstico e perda de uma chance}

O erro de diagnóstico ocorrerá por imperícia e será passível de responsabilização quando o médico, por exemplo, não souber interpretar exame realizado pelo paciente, chegando a conclusão errada, o médico não souber avaliar os sintomas e definir a doença que acomete o paciente, apesar das indicações claras.

O erro de diagnóstico, quando culposo, é grave, pois pode comprometer a chance de cura do paciente e resultar em danos não previstos pelo médico. $\mathrm{O}$ erro de diagnóstico pode levar a um erro de tratamento que poderá agravar o estado do paciente e lhe causar a perda de uma chance de cura, que é indenizável na medida da real chance de cura ou sobrevivência da vítima.

No Brasil, apenas 5\% das faculdades de medicina têm o estudo da Oncologia (como disciplina autônoma), que estuda o câncer, apesar de esta ser a segunda maior causa de mortes no País (KFOURI NETO, 2002, p.124). Desse modo, um médico que não é especialista em oncologia, por deficiência da universidade, não forma suspeita sobre câncer, justamente por ter conhecimento insuficiente de sua diagnose, permitindo que a enfermidade se desenvolva e as chances de cura do paciente diminuam.

O diagnóstico errado ou a falta dele poderá levar a uma responsabilização por imperícia baseado na teoria da perda de uma chance. $\mathrm{O}$ dano consistiria exatamente na perda da chance de cura ou sobrevivência, a conduta ilícita seria não proporcionar ao paciente a chance de cura pela falta de conhecimento/ habilidade que deveria possuir.

Essa teoria, segundo decisão da oitava câmara cível do Tribunal de Justiça do Paraná:

“[...] envolve chances perdidas, e apenas isso. É suficiente que existam chances sérias de cura ou de uma sobrevida menos sofrida, perdidas em razão da culpa do médico [...](TJPR - $8^{\text {a }}$ C.Cível - AC 817844-9 - Ponta Grossa

- Rel.: José Laurindo de Souza Netto - Unânime - J. 08.03.2012)”.

A chance de cura ou melhora deve ser séria e provável e sua perda deve ser certa. A quantificação do dano dependerá do grau de probabilidade de que a chance perdida seria realizada (KFOURI NETO, 2010, p.70). Não chegando, porém, ao valor efetivo do dano final. 
Apesar da discussão, a aplicação dessa teoria deve ser considerada um grande avanço, contudo o campo de sua aplicação deve ficar restrito aos casos em que ela é realmente apropriada, pois quase todas as decisões implicam no descarte de outras possibilidades, o que não significa dizer que são perdas de chances de cura ou sobrevivência (CASTRO, 2005, p.198).

\subsection{Prevenção do erro médico}

Estudos mostram que a maioria dos médicos que responde por erro está graduada há mais de 10 anos. A extensa atividade profissional oferece ao médico uma falsa segurança e o leva a deixar de estudar e se atualizar, deixando-o mais vulnerável a uma conduta imperita (GOMES; DRUMOND; FRANÇA, 2002, p.15).

Irany Novah Moraes (1998, p.37) estima que metade do que foi aprendido na graduação deixa de ser verdade em 8 anos, a evolução da medicina é muito rápida, daí surge a necessidade de constante atualização.

A licença médica nos Estados Unidos da América é estadual e tem validade de 3 anos, para renová-la o médico deve se manter atualizado e reciclar seu conhecimento, participando de um número mínimo de cursos, estágios e conferências (GOMES; DRUMOND; FRANÇA, 2002, p.9).

Além desta salutar medida, que exigiria dos médicos um constante aprimoramento e estudo, poderia ser adotado no Brasil um exame nacional e obrigatório para o ingresso na atividade médica, como o exame para ingresso na advocacia, que cumpre seu papel ao proteger o mercado de trabalho de profissionais que ainda não estão totalmente aptos para o exercício de seu mister.

A tomada de consciência de que o erro médico existe e traz consequências é o primeiro passo na luta contra ele. As medidas citadas seriam de grande utilidade para combater o erro médico qualificado pela imperícia, pois contribuiriam para eliminar a falta de conhecimento profissional que o caracteriza.

Não obstante, deve existir um maior rigor para aprovar a abertura de novos cursos universitários de medicina, exigindo efetivamente que eles cumpram os requisitos pré-estabelecidos, as escolas que já existem devem primar por um ensino de maior qualidade e majorar as exigências para com os graduandos. 
O perfil do aluno brasileiro também deve mudar, tornando-se um acadêmico mais ativo e responsável pela própria educação, não deixando nunca de se manter atualizado.

Conduta reprovável que leva ao ajuizamento de demandas infundadas causando injustiça à classe médica é a polemização do erro médico na mídia, que instiga muitas pessoas a questionarem condutas perfeitamente adequadas de seus médicos e buscar reparação de um dano que não foi por ele causado. Esta é uma atitude deveras irresponsável dos meios de comunicação que deve ser evitada e penalizada com mais rigor quando totalmente infundada, obrigando, assim, a imprensa a investigar o suposto erro médico com mais seriedade.

\subsection{Perspectivas}

Não se deve permitir a "satanização" do médico nem a "canonização" do paciente, ambos, como seres humanos cometem erros, contudo não se deve deixar uns pagarem pelos erros dos outros, nem ambos pelas imperfeições ainda existentes na medicina. Por isso se faz necessária a criação de um mecanismo mais eficiente de reparação dos danos médicos.

Socializar o erro médico seria a saída apontada por muitos doutrinadores, para reparar o dano no âmbito civil e dar tranquilidade ao médico. O programa de seguro social proposto deveria ser financiado por contribuições pagas pelos segurados e ser gerido pelo Estado, que, por não visar somente ao lucro, evitaria uma onerosidade excessiva (GOMES; DRUMOND; FRANÇA, 2002, p.106 e ss.).

Uma postura mais humana e atenciosa dos médicos também evitaria algumas reclamatórias, pois, ao reconhecer, se desculpar pelo erro e tentar repará-lo, o médico ganharia a simpatia do paciente, que reconheceria que erros acontecem mesmo quando há a melhor das intenções e que a falha é humana. Além do mais, uma melhora na relação médico paciente inibiria alguns erros que são causados pelo fato do médico enxergar o paciente como uma doença e não como uma pessoa, tratando-o assim com certa frieza.

Recomenda-se que todos os médicos tenham consciência que o estudo e aprimoramento contínuo são necessários, e para isso existem publicações especializadas, congressos, cursos, conferências, estágios, etc.

Uma revisão no ensino médico também é imperativa além da implantação de cursos de reciclagem obrigatórios. 


\section{CONCLUSÃO}

Conclui-se que há limitação da liberdade de agir do médico quando esta esbarra em regras unanimemente aceitas e procedimentos consagrados pela ciência médica. Ao médico não é dado experimentar e se arriscar com a saúde do paciente sem necessidade.

A imperícia, quando permeia a conduta médica, dá causa a modalidade de erro médico mais grave, pois é perfeitamente evitável. O profissional deve ter consciência dos limites de seu conhecimento e não se arriscar além dele.

É impossível ao médico dominar todas as áreas de sua profissão, porém deve dominar a que exerce.

Os julgadores devem ser cuidadosos e sempre se apoiar na prova pericial, pois a não ser quando o erro é grosseiro, os erros de técnica são difíceis de ser apurados, a própria conduta médica é discutível e às vezes controversa, o progresso técnico da medicina e a especialização cada vez maior torna difícil a sua apreciação.

Também, o juiz não deve se olvidar da opção que o legislador pátrio fez ao excetuar os profissionais liberais da abrangência da responsabilidade civil objetiva prevista no Código de Defesa do Consumidor, sua responsabilização é, e deve ser, dependente da verificação da culpa, sob pena de os médicos arcarem com danos que não provocaram e nem podem evitar.

Por fim, não se deve condenar a classe médica pela conduta culposa de alguns de seus pares, pois a profissão é exercida com probidade e dedicação pela maioria.

\section{REFERÊNCIAS}

BARROS JÚNIOR, Edmilson de Almeida. A responsabilidade civil do médico: uma abordagem constitucional. São Paulo: Atlas, 2007.

BUENO, Cassio Scarpinella. Curso sistematizado de direito processual civil: procedimento comum: ordinário e sumário. 2. ed. São Paulo: Saraiva, 2009, v. 2, t. 1.

CASTRO, João Monteiro de. Responsabilidade civil do médico. São Paulo: Método, 2005. 
CAVALIERI FILHO, Sérgio. Programa de Responsabilidade Civil. 8. ed. São Paulo: Atlas, 2008.

CROCE, Delton; CROCE JUNIOR, Delton. Erro Médico e o Direito. 2. ed. São Paulo: Saraiva, 2002.

DINIZ, Maria Helena. Curso de Direto Civil Brasileiro. 22.ed. São Paulo: Saraiva, 2008, v.7.

GOMES, Júlio Cézar Meirelles; DRUMOND, José Geraldo de Freitas; FRANÇA, Genival Veloso de. Erro Médico. 4. ed. Rio de Janeiro: Editora Guanabara Koogan, 2002.

KFOURI NETO, Miguel. Responsabilidade Civil do Médico. 7.ed. São Paulo: Editora Revista dos Tribunais, 2010.

. Culpa Médica e ônus da prova: presunções, perda de uma chance, cargas probatórias dinâmicas, inversão do ônus probatório e consentimento informado: responsabilidade civil em pediatria, responsabilidade civil em gineco-obstetrícia. São Paulo: Editora Revista dos Tribunais, 2002.

LOPEZ, Teresa Ancona. O Dano estético: Responsabilidade Civil. 3.ed. São Paulo: Editora Revista dos Tribunais, 2004.

MELO, Nehemias Domingos de. Responsabilidade Civil por Erro Médico: doutrina e jurisprudência. São Paulo: Atlas, 2008.

MORAES, Irany Novah. Erro médico e a lei. 4. ed. São Paulo: LEJUS, 1998.

SCHAEFER, Fernanda. Responsabilidade Civil do Médico e Erro de Diagnóstico. Curitiba: Juruá, 2010.

BRASIL. Superior Tribunal de Justiça. Segunda Turma. AgRg no AREsp 14.705/RS, Rel. Ministro HUMBERTO MARTINS, julgado em 13/09/2011, DJe 21/09/2011. Disponível em: <http://www.stj.jus.br/ 


\section{SCON/jurisprudencia/}

doc.jsp?livre=responsabilidade $+\mathrm{m} \% \mathrm{E} 9 \mathrm{dico} \& \& \mathrm{~b}=\mathrm{ACOR} \& \mathrm{p}=$ true $\& \mathrm{t}=\& \mathrm{l}=10 \& \mathrm{i}=25 \#>$. Acesso em 25 de maio de 2012.

BRASIL. Superior Tribunal de Justiça. Segunda Turma.

REsp 1184932/PR, Rel. Ministro CASTRO MEIRA, julgado em 13/12/2011, DJe 16/02/2012. Disponível em: <http:/www.stj.jus.br/SCON/jurisprudencia/ doc.jsp?livre $=$ responsabilidade $+\mathrm{m} \% \mathrm{E}$ dico $\& \& b=\mathrm{bCOR} \& \mathrm{p}=$ true $\& \mathrm{t}=\& \mathrm{l}=10 \& \mathrm{i}=15 \#>$. Acesso em 25 de maio de 2012.

BRASIL. Tribunal de Justiça do Paraná. $8^{\text {a }}$ Câmara Cível. AC 825484-8 - Londrina - Rel.: José Laurindo de Souza Netto - Unânime J. 08.03.2012. Disponível em: <http://portal.tjpr.jus.br/jurisprudencia/j/ 11252737/Acórdão-825484-8\#>. Acesso em 25 de maio de 2012.

BRASIL. Tribunal de Justiça do Paraná. $8^{\text {a }}$ Câmara Cível. AC 817844-9 - Ponta Grossa - Rel.: José Laurindo de Souza Netto Unânime - J. 08.03.2012. Disponível em: <http://portal.tjpr.jus.br/ jurisprudencia/j/11252724/Acórdão-817844-9\#>. Acesso em 25 de maio de 2012.

CONSELHO federal de medicina (CFM) divulga dados sobre a concentração de médicos no Brasil. Cremesc. 09 de abril de 2010. Disponível em: $<$ http://www.cremesc.org.br/noticias/2010/04/cfm-divulgadados-sobre-concentracao-medicos-brasil.htm>. Acesso em: 03 abr. 2011.

CREMESP defende exame obrigatório para recém-formados em medicina. Cremesp. 29 de maio de 2009. Disponível em: http://www.cremesp.org.br/ ? siteAcao=SaladeImprensa\&acao=sala_imprensa\&id=229. Acesso em: 03 abr. 2011.

CREMESP divulga levantamento inédito: Especialidades médicas.

Cremesp. 12 fev. 2008. Disponível em: <http://www.cremesp.org.br/ ? siteAcao $=$ SaladeImprensa\&acao $=$ sala_imprensa\&id $=196>$. Acesso em: 03 abr. 2011. 
ESTATÍSTICA. Conselho Federal de Medicina. Disponível em: http:// portal.cfm.org.br/index.php?option=com_estatistica. Acesso em: 03 abr. 2011.

Recebido em: 2012-04-25 Aprovado para publicação em: 2012-09-13

Como citar: VIZZOTO, Marília; MARQUESI, Roberto Wagner. Responsabilidade civil do médico imperito. Scientia Iuris, Londrina, v.16, n.1, p.25-44, jul.2012. DOI: 10.5433/ 2178-8189.2012v16n1p25. 